Article

\title{
Protection of Children in Difficulty in China during the COVID-19 Pandemic
}

\author{
Fang Zhao ${ }^{1}$, Ning Zhu ${ }^{1}$ (D) and Juha Hämäläinen ${ }^{1,2,3, *(\mathbb{D})}$ \\ 1 School of Social Development and Public Policy, Fudan University, Shanghai 200433, China; \\ zhaofang223@163.com (F.Z.); zhuning0627@163.com (N.Z.) \\ 2 Faculty of Social Sciences and Business Studies, University of Eastern Finland, 70210 Kuopio, Finland \\ 3 Faculty of Social Studies, University of Ostrava, 70200 Ostrava, Czech Republic \\ * Correspondence: juha.hamalainen@uef.fi; Tel.: +358-50-5939415
}

Citation: Zhao, F.; Zhu, N.;

Hämäläinen, J. Protection of Children in Difficulty in China during the COVID-19 Pandemic. Sustainability 2021, 13, 279. https://doi.org/ $10.3390 /$ su13010279

Received: 10 November 2020 Accepted: 25 December 2020 Published: 30 December 2020

Publisher's Note: MDPI stays neutral with regard to jurisdictional clai$\mathrm{ms}$ in published maps and institutional affiliations.

Copyright: (C) 2020 by the authors. Licensee MDPI, Basel, Switzerland. This article is an open access article distributed under the terms and conditions of the Creative Commons Attribution (CC BY) license (https:// creativecommons.org/licenses/by/ $4.0 /)$.

\begin{abstract}
This study investigated the resilience of the Chinese child protection system in responding to the special needs of children in difficulty under the specific circumstances caused by the COVID-19 pandemic. This study applied qualitative document analysis of child protection administrative documents, in-depth interviews with 13 child protection professionals, and an in-depth case study of 14 children living in difficulty, complemented by relevant information available in the media. The results indicate that there are good policies in China's child protection services but the organizational and functional fragmentation complicates implementation, suggesting a need for the development of bottom-up practices. The essential conclusion supported by these results is that the child protection system should be regarded and developed as a systematic project combining the legal, policymaking, and professional systems of child welfare services as well as governmental and non-governmental forces. As the COVID-19 pandemic has raised awareness of the need to develop the field of child protection holistically as an integrated system in terms of social sustainability in China, an international literature-based comparison indicates that the pandemic has also raised similar political awareness in other countries.
\end{abstract}

Keywords: COVID-19 pandemic; child protection; children in difficulty; sustainable system; public health emergency

\section{Introduction}

The COVID-19 pandemic in 2020 is a major public health emergency with extensive and far-reaching implications for different sectors of society and the world as a whole. This article discusses how the pandemic has been handled in China's child welfare system. The aim is to provide information on how the pandemic has been confronted at the system level, especially from a child welfare point of view, and what lessons have been learned from it.

There is a lot of international evidence, also from China, that SARS-Cov-2 causes the COVID-19 disease does not easily infect children and that infections in children are usually mild, although some children may have severe symptoms [1]. However, social isolation caused by lockdowns has been seen to increase the risks of domestic violence and child abuse and even to have "serious and long-lasting implications for the mental health of millions of children and their caregivers" [2] and to have "exacerbated personal and collective vulnerabilities while limiting accessible and familiar support options" [3]. In addition, it has been found that those who are the most vulnerable to negative social consequences are children and families who already have psychosocial problems [4].

Research on the social impact of the pandemic on the lives of children and families has paid particular attention to the effects of school closures on a child's schooling, relationships, and health in different countries $[5,6]$. However, the few studies conducted so far have presented fragmented research data on the ability of the child protection system to meet the 
challenges of a large and dangerous disease. In general, research shows that professionals' resilience in working in child protection must be fostered and supported by additional support [7].

In China, the epidemic spread rapidly and affected a large geographical scope, making it difficult to prevent and control, and thus presenting a significant risk for the entire society. In the face of such a major epidemic, children in difficulty are at particular risk and in need of special protection [4]; thus, this article discusses the social impacts of COVID19 especially on children in difficulty in the Chinese context, with particular reference to the challenges that COVID-19 poses to the child protection system.

The concept of "children in difficulty" was introduced in China in 2013 by the Ministry of Civil Affairs in its drive to build a "moderate and universal child social welfare system." Since then, the connotation and denotation of the concept have been changing along with social developments in the country. Early in 2013, "children in difficulty" and "children from families in difficulty" were two distinct concepts [8]; in 2014, the concept of "children in difficulty" was broadened to incorporate "children from families in difficulty" [9]; in 2016, the central government clarified the classification of "children in difficulty" as children in difficulty due to family circumstances, due to their own circumstances, or due to custody circumstances [10].

Children in difficulty due to family circumstances refer to those who grow up in poverty, and thus, have difficulty in daily life, medical treatment, or education. Children in difficulty due to their own circumstances refers to those who have difficulty in receiving rehabilitation and nursing due to their disabilities. Lastly, children in difficulty due to custody circumstances refers to those who are subjected to abuse, abandonment, or accidentally or intentionally inflicted injuries owing to lack of or improper family custody. No accurate figure of children in difficulty in China according to the aforementioned definition is available. However, according to statistics from various sources, 7.176 million children are included in the relief program for orphans, people living in dire poverty, and minimum subsistence allowances [11]; nearly 200,000 children who have parents but whose family is unable or unwilling to raise them; the 3.855 million disabled children between 0 and 14 years old are joined by 199,000 more every year; and 6.97 million children are rural left-behind children, who are rural minors under the age of 16 who cannot live with their parents normally because the parents both go out to work in another region or one of them goes out to work in another region and the other has no guardianship capacity. In addition, a considerable number of children are suffering abuse and neglect. In summary, the number of children in difficulty in China is quite sizable.

During the early outbreak of COVID-19 in China, as children were considered less susceptible to infection, special, prior protection was not given in time to children in difficulty and their families. As the severity of the epidemic grew, the issue of children in difficulty began to gain prominence. By discussing the child welfare measures in relation to the progress of the epidemic, this article endeavors to explain the measures that have been taken in China from a longitudinal perspective. Looking at child welfare activities at different stages of the epidemic's process, the analysis gives a time-determined picture of the relationship between the epidemic and child welfare. While child welfare systems and the dynamics of the epidemic vary from country to country, we can learn from countryspecific experiences and examples.

While the infection rate of children in difficulty is relatively low in general [12], they could face multiple risks and quandaries, such as disease prevention, rescue, and care, complicated by their fragility and the fragility of the social system. In studies focusing on children not in parental custody, poverty is often considered the primary reason for a lack of parental care [13], which can result in problems for children, such as malnutrition and crowded living spaces. Further, malnutrition can lead to damage to the immune system [14], and crowded living spaces can increase the possibility of virus transmission [15].

In addition, children in difficulty may grow up in inter-generational households [16] and be cared for by grandparents or elder relatives, whose ability to provide care has been 
weakened by COVID-19. At the same time, secondary disasters may affect children in difficulty during the pandemic. For example, in the fight against COVID-19, the Chinese government issued a home quarantine policy, which undoubtedly increased the pressure on many poor families that had already been under economic pressure. The inability to work means no income and, thus, the inability to bear daily expenses, such as food, utilities, and rent. Several studies also indicate that children are more likely to be abused during the current COVID-19 pandemic $[17,18]$.

Supporting and protecting children during a major crisis is a global challenge requiring joint efforts by the government and the society to lend a helping hand to children and their families. Government policies, laws, and regulations will affect the lives and future development of children in difficulty as well as the lives of their families at the macro level. Some scholars have suggested that the government should introduce subsidies and tax reduction policies for children and families affected by the COVID-19 pandemic and modify and improve relevant legal provisions [19]. Moreover, social organizations, as the third party in addition to the government and the market, should play an important role [20]. However, it may be difficult for social organizations to act quickly due to quarantine measures, and in the face of various restrictions, it may be difficult for organizations to determine how to best support children and families in difficulty [21].

On 24 January 2020, the father of a single-parent family in Hubei province was quarantined for suspected SARS-Cov-2 infection. His 17-year-old son, who suffered from quadriplegia and cerebral palsy, was left home alone for six days before dying on January 29 [22]. On February 24, social workers in a community in Hubei province found that a 71-year-old man had died at home many days earlier. The child in the home, aged five or six years old, survived by eating biscuits. The child thought his grandfather had fallen asleep and covered him with a quilt. When he was asked why he did not go out for help, the child said that his grandfather told him, "there is a virus outside, so never go out" [23]. It is not difficult to understand that children growing up with guardians with weak custody capabilities are more likely to see their physical and mental health, and even their lives, endangered due to lack of custody as a result of the pandemic. For example, Li, a 15-year-old girl in Dengzhou, Henan province, had to share a smartphone with her two siblings to take online lessons, as her family was too poor to buy one for each of them. On February 29, Li was to take an online exam. She was so desperate after having to wait a long time to use the phone that she committed suicide by taking toxic pills [24]. In addition, the mother of a six-year-old boy with autism was unemployed, and thus, unable to pay the rent, let alone her son's rehabilitation training. In despair, she abandoned her child in front of an orphanage. These cases exemplify the difficulties that children face as a result of various secondary disasters relating to the pandemic.

There are more than 300 million children in China, and the pandemic poses an even greater challenge for the survival and protection of children who are already in difficult situations. This study aimed to explore and examine the Chinese solution for intervening in cases of children in difficulty based on the real-life context of children in difficulty during the COVID-19 pandemic.

\section{Materials and Methods}

This study adopts the multiple mutual proof method which comprises four stages. Initially, the method is concerned with understanding the diverse needs of children in difficulties as a result of the COVID-19 pandemic, based on cases of children in difficulties reported in the media and cases arising from actual services dealing with COVID-19. Secondly, the response policies of the central and local governments are established for the pandemic-related period in question. Thirdly, the position of multi-subject participation in policy implementation is explored using in-depth interviews. Finally, the effect of policy implementation and existing problems are analyzed for each case. Specific research methods include: 
1. Document analysis. Document analysis was conducted on policies issued at the national and local levels on protecting and caring for children during the pandemic; the work report on services for children in difficulty during the pandemic in Shanghai and Guangzhou; media reports on the protection of children in difficulty; and the minutes of a seminar held in Shanghai on the protection of children with COVID-19.

2. In-depth interview method. Thirteen in-depth interviews were conducted with relevant government staff engaged in child welfare work, child social workers, social workers working with children in difficulty, child welfare directors, child welfare supervisors, and medical and social workers in children's hospitals (see Table 1 for the list of interviewees). The thirteen interviewees were chosen because of their involvement with the Shanghai children's protection program "Love Around Children", which is discussed later in this article. The program comprises multiple areas in child protection policy implementation. Due to the pandemic, seven of the thirteen interviews were conducted online, the rest were one-on-one interviews. The interviews were conducted in accordance with the semi-structured interview outline prepared in advance. All interviewees were informed of the purpose of the interview and their consent was obtained before the interview. The main contents of the semi-structured interview included the problems that were to be solved through the policy; the path and guarantee mechanism of policy implementation; difficulties in implementing the policy; the interviewees thoughts on feasible solutions.

3. Case analysis. In-depth case analysis was conducted on 14 cases collected in Shanghai involving 16 children in difficulty — eight boys and eight girls with an average age of nine-and-a-half years (see Table 2 for the list of cases). Among the 14 cases, 12 are typical cases of child protection in Shanghai, and services from the government are being received during the pandemic. The other two cases were provided by medical social workers in the children's hospital; these two children are migrant children who do not have Shanghai "Hukou" (koseki) and were not covered by the local government program. The main content of case coding analysis included the main problems faced by the children; who is helping them; the main resources to help them; the children's problems that have been solved; and reasons why problems have not been solved.

Table 1. Interviewees.

\begin{tabular}{llll}
\hline Number & Gender & Place of Work & Position \\
\hline 1 & Male & Child Welfare Office, Civil Affairs Bureau & Division Director \\
2 & Female & Government Temporary Child Care Centre & Section Chief \\
3 & Female & Government Assistance and Protection Center for Minors & Staff Member \\
4 & Male & Street and Civil Affairs Department & Child Welfare Supervisor \\
5 & Male & Street and Civil Affairs Department & Child Welfare Director \\
6 & Female & Children's Social Work Service & Director General \\
7 & Female & Children's Social Work Service & Social Worker \\
8 & Female & Children's Social Work Service & Social Worker \\
9 & Female & Children's Medical Center & Medical Social Worker \\
10 & Male & Social Work Service Agency for Children in Need Project & Social Worker \\
11 & Male & Children's Service Project of Social Organization & Social Worker \\
12 & Male & Social Organization (related to child protection laws) & Senior Researcher \\
13 & Female & Social Workers Association of the District & Deputy Secretary \\
\hline
\end{tabular}


Table 2. Cases.

\begin{tabular}{|c|c|c|c|}
\hline Number & Gender & Age & Cases \\
\hline 1 & Male & 8 & $\begin{array}{l}\text { Single-parent family, divorced parents. The boy lives with his father. The father } \\
\text { stabbed the child with a knife him when he was drunk. }\end{array}$ \\
\hline 2 & Male & 5 & $\begin{array}{l}\text { Single-parent family and non-local registered permanent residence. The father has a } \\
\text { slight intellectual disability and does some odd jobs for a living. There are two } \\
\text { children in the family. The elder son has severe Type I Diabetes. The father cannot } \\
\text { afford insulin and often forgets to inject insulin for his son. The elder son has been } \\
\text { sent to the hospital several times for rescue. }\end{array}$ \\
\hline 3 & Female & 14 & $\begin{array}{l}\text { Single-parent family. The girl lives with her father and grandparents. The mother has } \\
\text { seldom had contact with the girl since the divorce. The father will beat the girl quite } \\
\text { hard when she has academic problems. The grandmother could not help but call } \\
\text { the police. }\end{array}$ \\
\hline 4 & Female & 13 & $\begin{array}{l}\text { The girl's mother takes drugs, gave birth out of wedlock, and does not know who the } \\
\text { girl's father is. The mother seldom disciplines her. The girl often stays at home alone, } \\
\text { sometimes fools around with some hooligans, and does not come back home at night. } \\
\text { The girl has been caught skipping classes and sleeping in class and, consequently, } \\
\text { her academic performance is very poor. }\end{array}$ \\
\hline 5 & Male & 10 & $\begin{array}{l}\text { The boy's father is serving a prison sentence and the mother ran away from home. } \\
\text { The boy lives with his grandparents. The grandparents said they are unable to } \\
\text { discipline him. The boy's academic performance is very poor, and they do not know } \\
\text { how to help him take classes online during the pandemic. }\end{array}$ \\
\hline & & & $\begin{array}{l}\text { Single-parent family. The girl lives with her mother, who is grumpy and demanding } \\
\text { and often scolds and beats her. The grandparents have called the police several times. }\end{array}$ \\
\hline 6 & Female & 9 & $\begin{array}{l}\text { The police issued a domestic violence warning, and the Women's Federation has also } \\
\text { visited the family several times, but the mother was unmoved, believing this was her } \\
\text { business and should not be considered domestic violence. }\end{array}$ \\
\hline 7 & Female & 7 & $\begin{array}{l}\text { The girl has a congenital disability (rickets) and good family conditions. The girl has } \\
\text { reached school age but does not go to school. The school intended to send a teacher to } \\
\text { her home to provide education, but the parents refused. They believe the girl has no } \\
\text { future. As long as they provide care and money, there is no need for the girl to study. }\end{array}$ \\
\hline 8 & Male & 14 & $\begin{array}{l}\text { The boy's mother passed away one month after his birth. The father left Shanghai } \\
\text { after selling their house and seldom contacted him. Recently, the father died. } \\
\text { The grandmother is still alive but is too old to look after the boy. At present, the boy is } \\
\text { at his aunt's house, but her financial condition is not very good. The boy is in a } \\
\text { rebellious period and is unwilling to follow his aunt's education. He often goes to the } \\
\text { game room, Internet cafes, and other places. }\end{array}$ \\
\hline & & & $\begin{array}{l}\text { The girl was born with an underdeveloped heart and has no registered permanent } \\
\text { residence. Her mother is a migrant worker and gave birth to her out of wedlock. } \\
\text { The girl's mother left her in front of a neighbor's house and never returned. }\end{array}$ \\
\hline 9 & Female & 10 & $\begin{array}{l}\text { The mother said she was unable to support the girl, so she asked social worker to find } \\
\text { the father. The girl's father is a Shanghainese but married, so he is unwilling to take a } \\
\text { paternity test and bear responsibility for the girl. The girl's guardianship and } \\
\text { household registration issues and medical problems cannot be resolved. }\end{array}$ \\
\hline 10 & Male & 15 & $\begin{array}{l}\text { Single-parent family. The boy originally lived with his father and grandfather, and his } \\
\text { father has been receiving compulsory drug treatment. His mother left Shanghai after } \\
\text { the divorce. Recently, the grandfather passed away suddenly, and the boy's living } \\
\text { situation became a problem. The neighborhood committee tried to contact his mother } \\
\text { and found her dead. At present, the child lives alone. The boy has an aunt, } \\
\text { but because of his father's drug problem, the aunt is unwilling to take care of the boy. } \\
\text { She is only willing to be responsible for the safekeeping of the inheritance left to the } \\
\text { boy by his grandfather and pay living expenses and other relevant expenses } \\
\text { every month. }\end{array}$ \\
\hline 11 & Female & 8 & $\begin{array}{l}\text { The family is faced with financial difficulties. The parents are getting divorced because } \\
\text { of family disputes. The neighborhood committee mediated several times in vain. } \\
\text { At present, neither of the parents wants the girl. The mother is somewhat disabled } \\
\text { (poliomyelitis) and says that she cannot take care of the girl. The father also says that } \\
\text { he does not want custody of the girl and that a daughter should be with her mother. }\end{array}$ \\
\hline
\end{tabular}


Table 2. Cont.

\begin{tabular}{|c|c|c|c|}
\hline Number & Gender & Age & Cases \\
\hline 12 & Male & 13 & $\begin{array}{l}\text { The boy's mother took drugs, gave birth out of wedlock, did not have a registered } \\
\text { permanent residence, and did not go to school. He lives on take-out food, is very fat } \\
\text { and lacks the ability to communicate with people. At present, the mother is forcibly } \\
\text { abstaining from taking drugs. The mother's boyfriend left the boy at the police station. } \\
\text { He is living in a temporary care center now. }\end{array}$ \\
\hline 13 & Female & 12 & $\begin{array}{l}\text { The girl was born out of wedlock. Her mother is serving a prison sentence. The girl } \\
\text { was diagnosed with schizophrenia at the end of last year and stayed at home for a } \\
\text { year. At present, her guardian is her grandmother, who is too old and sick to look } \\
\text { after her. }\end{array}$ \\
\hline 14 & $\begin{array}{l}\text { Male, } \\
\text { Female, } \\
\text { Male }\end{array}$ & $6,5,3$ & $\begin{array}{l}\text { All three children were born out of wedlock. Both parents are drug addicts. Since } \\
\text { March 2012, the mother has been involved in drug trafficking. As she was pregnant at } \\
\text { the time, she served her sentence in the community. The mother was arrested for drug } \\
\text { trafficking on March } 6,2018 \text {, and the total sentence was nearly } 18 \text { years. The eldest } \\
\text { son's father has served six years in prison and will be released in } 2020 \text {. The fathers of } \\
\text { the other two children are unknown. The three children are temporarily under the } \\
\text { supervision of their grandmother, who is also a drug addict and has just completed } \\
\text { three years of drug rehabilitation. }\end{array}$ \\
\hline
\end{tabular}

The overall material thus consisted of three sub-materials: relevant child protection policy documents, interviews with experts working in the field, and case-specific materials with children in difficulty. Data analysis was performed as follows:

First, transcripts of the in-depth interviews were made. Following this, thematic analysis was adopted to analyze and refine the text data. The themes or important categories arising from the raw data were the intervention process; resource status and difficulties encountered during the pandemic; and the most frequently occurring and most considered problems. Thirdly, based on the above themes and categories, the materials were further refined and verified with policy and case study data, and the corresponding conclusions were finally drawn.

This study was approved by the Ethics Committee of The School of Social Development and Public Policy of Fudan University. The ethical review approval number is FDU-SSDPP-IRB-2020-2-007.

\section{Results}

The emergence of the COVID-19 pandemic disrupted the normal social order. While the government was concentrating on solving major issues affecting the overall situation, it was difficult to take into account the needs of some special groups. However, the aforementioned death of the child with cerebral palsy in particular exposed these needs and attracted the attention of the government and society. The policies formulated by the central government, quickly executed by the local governments and enhanced by effective cooperation with social organizations, created a safety net to protect children in difficulty.

\subsection{Government Response}

The government's response mainly consisted of a series of policies formulated to protect children in difficulty during pandemic control. The government quickly issued a series of policy documents that created synergies across ministries. The issuing units were mainly the State Council and the Ministry of Civil Affairs, high in hierarchy and strong in effect. The policy documents mainly addressed two aspects: on the one hand, protecting children without or lacking proper guardianship, and on the other hand, cooperation between the government and non-governmental social organizations.

\subsubsection{Protecting Children without or Lacking Proper Guardianship}

On 11 February 2020, the Ministry of Civil Affairs issued the "Notice on the Work of Rescue and Protection of Children Lacking Custody Due to COVID-19 Epidemic" [25]. 
This is the earliest relevant policy document, issued only 12 days after the death of the child with cerebral palsy. The notice requires timely report on the identification of qualified children, temporary care conditioned by different situations, strengthened rescue and social care, and the availability of a rescue and protection hotline for children lacking proper guardianship due to the impact of COVID-19. This notice made the rescue and protection of children without proper guardians due to the impact of COVID-19 a hot issue and attracted great attention from professionals doing child-related work in local governments, communities, and other relevant organizations.

Subsequently, on March 15, the State Council issued the "Work Plan for Relief and Protection of Children Lacking Custody Due to COVID-19 Epidemic" [26], further deploying the rescue and protection of children lacking guardianship due to the impact of COVID-19. The plan clarifies that children lacking custody refers to those whose parents or other guardians have confirmed infections, or are suspected of infection, or need to be quarantined for further observation, and those whose parents or other guardians are unable to fully perform their duty of care and custody due to the need to fight the pandemic or other impacts of COVID-19. The plan includes in the scope of protection children in difficulty due to the absence of temporary custody caused by the pandemic, in addition to those who are in difficulty due to chronic custody circumstances. Other major improvements compared with the notice issued in February are as follows.

(1) In terms of the report on the identification of qualified children, in addition to the responsibilities of child welfare director (also be called barefoot social worker) and child welfare supervisor in the township/sub-district and village/neighborhood committees, the notice clarifies the reporting obligations of medical workers providing on-site services, teachers, community workers, social workers, volunteers, and relevant charitable organizations. The notice also emphasizes the discovery, reporting, and referral role of the women's rights protection service hotline.

(2) There are four provisions for further implementation of custody and care responsibilities. First, the notice clarifies that, if a child's parents or other guardians cannot fully perform the duty of raising in custody due to the impact of the COVID-19 pandemic, the village/neighborhood committee shall urge them to entrust other persons with guardianship capabilities to take care of the child on their behalf. Second, if there is no legally qualified guardian, the village/neighborhood committee shall be responsible for temporary care. Third, where there are actual difficulties, the county-level civil affairs department shall assume temporary custody. Lastly, for children whose care is entrusted to a dedicated person, a child protection supervisor/chief, executive committee member of a grassroots women's federation, or community/social worker shall be designated to take all-round responsibilities, paying home visits or conducting telephone follow-ups at least twice a week to track the condition of custody.

(3) The notice clarifies that rescue and assistance shall be provided to children and families in difficulty due to the impact of the pandemic. Temporary assistance shall be provided in a timely manner in accordance with relevant laws and regulations. Medical institutions shall have a green channel in place for treating children. The government shall support social workers and other professionals in providing psychological counseling, spiritual care, and family companionship services for children of different ages. Rescue and protection agencies for minors shall actively participate in the fast response, temporary care, service referral, case tracking, resource sharing, and other services for children without guardians.

(4) The rescue and protection of children lacking custody shall be strengthened through various measures, including assigning the leading role to civil affairs departments at all levels, women's federations, and women's and children's working committee offices, ensuring adequate financial support, increasing government procurement of services, and strengthening supervision. 
3.1.2. Protecting Child Welfare Institutions, Special Child Groups, and Families Affected by COVID-19

The State Council issued the "Notice on Further Improving the Epidemic Prevention and Control Work of Civil Service Agencies" [27] on 28 February 2020. The notice emphasizes the importance of access management, staffing, and material supply to institutions, such as child welfare institutions and rescue and protection agencies for minors. The notice requires the firm implementation of early discovery, early reporting, early quarantine, and early treatment. Moreover, it stipulates that visits should be organized for members of special groups such as minors quarantined at home, orphans not living in orphanages, left-behind children, and timely assistance shall be provided.

Subsequently on April 1, the Ministry of Civil Affairs and the State Council Leading Group Office of Poverty Alleviation and Development issued a notice on the "Social Assistance Action Plan for Poverty Alleviation," [28] which provides a social assistance action plan for poverty alleviation regarding children in special difficulty, such as the rural left-behind children, orphans, children who have parents but whose family is unable or unwilling to raise them (de facto orphans), children living in poverty, as well as disabled children. The plan stresses the proper handling of individual cases through joint efforts by relevant governmental departments to guide the participation of social organizations, charity, social workers, and voluntary services. To further care for left-behind children and children in difficulty in rural areas, the Ministry of Civil Affairs issued a notice on organizing the nationwide "Policy Advocacy into the Village/Neighborhood" activity for the care and protection of rural left-behind children and children in difficulty on June 1, Children's Day [29]. The purpose of the activity is threefold: to guide parents or other guardians to strengthen the sense of responsibility for custody and provide proper care, to guide village/neighborhood committees in carrying out their responsibilities, disseminating relevant laws and regulations to guardians, supervising and guiding the custody of guardians, and to guide child welfare director in further improving the professional skills and providing prompt and targeted care services to better protect the basic rights and interests of children.

On July 29, when China was already in a later stage of dealing with COVID-19, the Ministry of Civil Affairs and the Ministry of Finance jointly issued a document expanding the age of minors qualifying for allowances for extremely poor people from 16 to 18 [30]. On August 5, the CPC Central Committee and the General Office of the State Council jointly issued the "Opinions on Reforming and Improving the Social Assistance System," [31] offering corresponding education assistance to students from families qualifying for the minimum living guarantee or allowances for extremely poor people, and students for whom receiving compulsory education is not suitable due to physical and mental disabilities, by means of reduction or exemption of related fees, granting of scholarships, arranging work-study positions, and sending teachers to provide home schooling according to the needs and actual conditions of different education stages

During this pandemic, the government has also strengthened the care and protection of minor children of prisoners and drug abusers. On 5 August 2020, the Ministry of Civil Affairs and the Ministry of Justice jointly issued the "Notice on the Care and Protection of Underage Children Lacking Custody of Persons in Custody and Compulsory Isolation for Drug Rehabilitation," launching the special actions of "Caring for Children of Persons in Prison and Drug Abusers" and establishing a regular care and protection mechanism [32].

Local governments quickly carried out the policies. Shanghai serves as an example. On February 5, the Civil Affairs Bureau of Shanghai formulated the "Work Specifications to Prevent and Control the Epidemic for Child Welfare-Related Sectors in Shanghai," requiring district governments to include children in difficulty, especially those lacking guardianship due to COVID-19, in the community epidemic prevention and control system. The government of Shanghai adapted the social service hotline into a rescue and protection hotline for children in difficulty during the pandemic. This enables any unit or individual to immediately call to report unsupervised and unattended children in difficulty in the 
community. After the report is accepted, it must be handled in accordance with the "Shanghai Municipality Working Regulations for the Safety Protection of Children in Difficulty" to ensure the safety of children. At the same time, a management system of one file per person, one question per day, and one report per day for children in difficulty is adopted to actively care for the daily lives and learning of children in difficulty and offer help when necessary.

As for the protection of children with special needs, taking children growing up in families suffering from drug addiction as an example, the government cooperates with social organizations specializing in community drug rehabilitation to screen out children in difficulty from the 11,322 children in families struggling with drug addiction in the city of Shanghai and groups them into three categories: (1) lacking custody or lacking proper custody; (2) guardian(s) suffering from serious diseases, disabilities, or poverty; and (3) children themselves suffering from disabilities or serious diseases, or absent household registration. The "Implementation Plan for the Care of Minor Children of Drug Addicts in Shanghai (2020-2022)" was formulated to strengthen care and assistance for the underage children of drug abusers.

In May, the Civil Affairs Bureau of Shanghai issued the "Love around Children: Work Plan for the Children in Difficulty Assistance Project", [33] which provides a tailor-made assistance plan for children in difficulty due to lack of custody or lack of proper custody as a result of the COVID-19 pandemic. The tailor-made assistance includes professional and customized social services covering areas such as family guardianship guidance, education assistance, daily care, psychological counseling, behavior correction, and social integration (see Figure 1 for details).
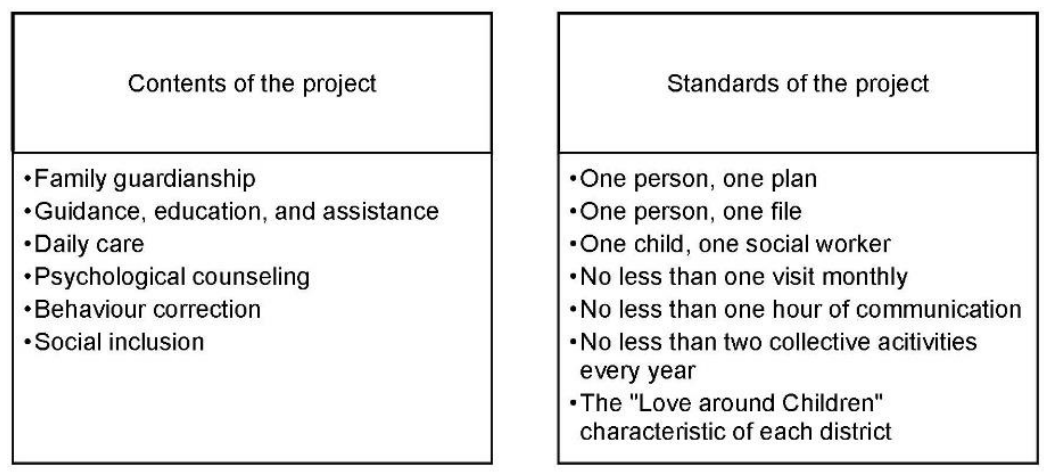

Figure 1. Contents and standards of "Love around Children"- an assistance and care project for children in difficulty in Shanghai.

In summary, the Chinese government has formulated a series of policies on the protection and rescue of children in difficulty during major public health incidents, which have been incorporated into the public health emergency management system. Preemptive measures have been taken to prevent and avoid risks to children arising from the COVID-19 pandemic and secondary disasters. Such policies are the cornerstone of the welfare and protection of children in difficulty in China during the pandemic. Currently, there are 1217 child welfare institutions caring for approximately 65,000 orphans and 1806 rescue and protection agencies for minors providing temporary care for a total of 5675 children in difficulty since January 2020. Not a single person in the aforementioned institutions was infected during the pandemic [34]. Such an achievement is due to the remarkable efforts of all levels of government.

\subsection{Cooperation between the Government and Non-Governmental Social Service Organizations}

Once a policy is in place, there is a need for specific services to implement it. The Chinese government has been conducting effective exploration in this regard. Cooperation 
between the government and the organizations in charge of providing professional services is characterized as "last mile" action in an emergency.

First, it was essential to set up a hotline to identify children in difficulty in the community. There has never been a unified hotline for children's assistance and protection in China. Therefore, during early outbreaks, the government temporarily used the women's rights protection service hotline to identify, report, and refer children's lack of guardianship. Since COVID-19 has been largely contained in China, the country has resumed work, production, and classes gradually. On 7 September 2020, the Ministry of Civil Affairs issued the "Notice on Designation of the Unified National Child Rescue and Protection Hotline Pilot Area" [35] comprising five provinces (regions) and 14 cities with a unified hotline number. In addition, the notice defined the hotline acceptance issues, identified responsible institutions or teams, and established a linkage mechanism for departments of the civil affairs system at all levels. COVID-19 made it difficult to make offline visits. This timely measure broadened the channels for children's aid and protection, making children's rescue and protection more convenient, quicker, and more effective, and better protecting the rights and interests of children.

Second, it was necessary to establish a "three-layer" working network and to deliver the service to the "last mile." In 2010, the Ministry of Civil Affairs and UNICEF had jointly launched China's "Child Welfare Demonstration Project" and established the post of child welfare director in village/neighborhood committees to explore the grassroots child welfare and protection service model. In 2016, the child welfare director model was written into China's national policy. In July 2017, the Ministry of Civil Affairs put forward specific requirements for the construction of social worker teams in the field of children protection and the deployment of child welfare director and child welfare supervisors. In 2019, the child welfare director model in village/neighborhood committees was spread across the country. Currently, there are 620,000 child welfare directors and 48,000 child welfare supervisors nationwide. During the COVID-19 outbreak, China issued a document assigning authority to child welfare supervisors and child welfare directors, and this workforce has played an important role during this unprecedented period.

The child protection chiefs model aims to establish a three-layer network to address the problem of children and families' poor access to government and social resources. The three layers refer to the establishment of institutions for the rescue and protection of minors in the civil affairs departments of districts and counties, the designation of child welfare supervisors in sub-districts, and the designation of one child welfare director in each natural village, thereby establishing a three-layer network of counties (cities, districts, and banners), townships (sub-districts), and villages (neighborhoods) to provide children's services to the "last mile".

Through the child protection director model, child protection work has reached the village level, shifting from passive acceptance to active detection. During the COVID-19 pandemic, child protection chiefs have collected information on all children in villages through a combination of online and offline work, screened out children in need through assessments, classified them into categories and established files, and delivered targeted services through reporting, introducing resources, and referrals to ensure that no child in need is left behind. The extremely dangerous and insidious pandemic has tested the resilience and performance of the system.

Consider, for example, Guangzhou, the sixth most populous city in China. In 174 towns, 2725 villages and communities were equipped with child welfare directors and child welfare supervisors, and child rescue and protection centers were set up in every district. Furthermore, Shanghai has established a grassroots team of children's workers consisting of 255 child welfare directors and 6174 child welfare supervisors, creating a protective net around children. In the districts of both cities, the pandemic response concerned all levels of the system.

Third, the government and social service organizations have cooperated to provide professional social services. The government's policy tools have stimulated more social 
dynamism. By the end of 2019, there were 866,000 social organizations in China [36], making them an effective supplement to the government's social services. After the outbreak of COVID-19, some social organizations immediately devoted themselves to the relief and protection of children in difficulty, such as providing services for children from migrant worker families, services for children with disabilities, rural left-behind children, and children from poor families, as well as to the provision of services for children with difficulties in accessing online classes.

In Guangzhou, for example, the government enlisted professional services provided by 54 social organizations, including 42 social service agencies, such as the Guangzhou Caring Center for Children in Difficulty, nine social groups, and nine foundations, and organized 22 training courses and trained 1763 child welfare social workers. The Civil Affairs Bureau of Shanghai raised RMB 5.9 million during the pandemic and enlisted services from 16 professional social organizations. By assigning one professional child welfare social worker to each child in difficulty, a long-term mechanism of "one-on-one" interactive feedback between social workers and children in difficulty was established. Consequently, the problems encountered by children were solved by professional methods. Among the 14 cases studied in this paper, four cases were discovered by community social workers for drug rehabilitation, two were referred by medical social workers at children's hospitals to family social workers in the community, two were identified as a result of family members calling the police, and the remaining six were identified by child protection chiefs in the community. At present, social organizations are following up on and intervening in these cases.

After a professional assessment, all social forces are linked to either provide direct aid to the children or to enhance the family's guardianship capacity. In particular, for some particularly difficult cases, a liaison meeting system has been set up at the township level, convening relevant officers from various government departments, with a deputy town chief (or deputy county chief) in charge of coordinating the intervention of resources. Cases 4, 6, 12, and 14, for example, were difficult to intervene in and were repeatedly discussed during liaison meetings. Child protection experts from colleges and universities were also invited to express their opinions on these cases. Owing to the coordination in the liaison meeting, the child in Case 4 was enrolled in a boarding school; in Case 6, the procuratorate issued a personal protection order and carried out parental education for the mother; in Case 12, the child was given a special household registration and a specific school was coordinated to accept the child; and in Case 14, the Civil Affairs Bureau gave the child a subsidy of RMB 1900 per month, recruited volunteers to assist the grandmother in caring for the child, and the child protection chief came to the door every week to track the grandmother's guardianship.

In the policy documents, the word "difficulty" in "children in difficulty" does not refer to an individual child in difficult circumstances, or to the environment in the usual sense, but to the interaction between people and the environment, incorporating the concepts of maximizing the interests of children, child-centeredness, and child participation into daily services. What is reflected in this is the government's and social organizations' formation of a holistic response mechanism in the face of a major public health emergency and rapid deployment of measures to solve these social problems.

\subsection{The Pandemic's Revelation of the Need for Development}

The protection of children in difficulty in major epidemics/pandemics is a complex and systematic task. During the early stage of the COVID-19 outbreak, the country lacked an effective emergency management mechanism for the protection of children in difficulty. However, as problems emerged, the central and local governments took immediate action and issued several policies related to children in difficulty in succession, and on the basis of policy formulation, implemented the policies through cooperation between the government and social organizations. On the whole, China has made great achievements in responding 
to the pandemic and in rescuing and protecting children in difficulty. However, looking back, we do find some problems that need further exploration.

(i) The legislation of child protection has a long way to go.

With the promulgation and revision of various laws and regulations, such as "China's Anti-Domestic Violence Law" and "Law on the Protection of Minors," child protection efforts have continued to increase. According to China's judicial data in 2018, from 2013 to 2017 , the number of child protection cases in the country showed an overall upward trend, increasing from 83,000 in 2013 to 118,000 in 2017, with an average annual growth rate of $10.46 \%$. However, up to now, China does not have a unified child welfare law. Although law on the protection of minors was amended in October 2020 and has been greatly improved, there are many different policies that are fragmented and difficult to unify. There are difficulties in connecting welfare services with laws. In May 2020, the Supreme People's Procuratorate, together with other ministries and commissions, specially promulgated the "Opinions on Establishing a System for Compulsory Reporting of Cases against Minors (for Trial Implementation)." However, its implementation lacks the support of relevant services and its operation is fraught with difficulties. Among them, a particular problem is the lack of legally authorized professional assessment, as well as how to follow up after the report is published. The operating subject and process are unclear.

"In fact, we found out that these two children were victims of domestic violence and severe neglect and were still at great risk after discharge. We knew there was a mandatory reporting system, but we didn't report it to the police. Based on our past experience, it's useless to report. Some of the children's household registrations are in other jurisdictions, and the police are even reluctant to treat them, saying that they are not in charge of them, and let us find the police of the child's local registration base instead." (Medical social worker at a children's hospital; Cases 1 and 2)

"When we intervened, we found the mother very difficult to convince and wild, threatening that if we call the police once, she would beat the child up once. However, we had no choice but to report it to the police. When the police came, it was only a reprimand and nothing more substantial was done." (Children's social worker of the Children's Agency; Case 6)

"When the father beat the child, the grandma could not stop it and called the police. But when the police came, the grandma refused to allow the police to take the child for an injury test for fear that they would arrest her son. It is difficult to reconcile love and law, and it was left unattended." (Child protection chief; Case3)

(ii) The establishment of child protection system needs to be further improved and institutionalized.

At present, everyone is fully aware of the importance of child protection, but the construction of a child protection system has yet to take shape. The fact that so many policies were issued at once during the COVID-19 crisis shows, on the one hand, that China attaches importance to children's rights and interests, but on the other hand, that there are too many gaps in this area. In fact, these measures seem to represent a temporary "remedial class." For example, caring programs for children in difficulty have been implemented nationwide, but they have not been institutionalized into the social structure and especially lack clear and continuous financial support. There are problems in how to develop them sustainably. Currently, welfare services are strictly limited by the household registration system and effectively exclude non-resident or non-local households.

Local policies, child welfare directors, child rescue and protection centers, and community services actually exclude a large number of migrant children. As a result, grassroots child welfare directors and child welfare supervisors offer a very good set-up rooted in the community, where children in difficulty can be quickly identified and reported for 
early and timely intervention. However, most of these chiefs and supervisors are part-time civil affairs officers in the community without any subsidies. Their regular work leaves them with little energy or motivation. District and county civil affairs bureaus have set up child rescue and protection centers, but most of them are only physical spaces lacking staff. Owing to the lack of professionals, they do not know how to follow up and, consequently, do not really operate. Evidently, although the pandemic has promoted the development of child protection in China, these gaps still exist. There is still a long way to go for the institutionalization of the child protection system.

"When a document was issued, I really wanted to give some impetus. But without follow-up support, how long this work can last is really uncertain. We want to push it forward, but we find that we are often 'stuck' in many places and can't move." (Children's social worker at WFWP)

"At present, this project is promoted by the civil affairs departments, mainly like a 'safety net.' The targeted service groups are strictly limited. The service to children in difficulty mainly concentrates upon hardship allowance. Children who do not have household registration in this city are not in the scope of services. In addition to hardship allowance, some other needs of children and families are still very difficult to meet." (Social worker of a social organization)

"Children Rescue and Protection Center? We do have that, and the facilities are ready, but it's just a center in name only, and it hasn't been activated once. The center's staff members are also part-time staff from welfare institutions. I know there should be professional social workers, I know, but..." (Child protection supervisor)

"Although I am a child protection chief, my main job is civil affairs in the community. I really want to help these children, but I often don't have the energy to do so. Sorry, there are too many things to do." (Child protection chief)

"At present, almost all child protection chiefs in rural areas are part-time and there is no subsidy. Only some projects funded by foundations will have a small subsidy. So, doing it has a lot to do with people, and people who are capable and caring will do more." (Deputy Secretary General of District Social Workers Association)

(iii) There is an urgent need to expand the pool of professional children's social workers.

As China's child protection work continues to advance, the demand for children professionals is becoming increasingly urgent, especially as children's needs shift from survival to protection and assistance, placing even greater demands on the abilities of children workers. For this reason, the Ministry of Civil Affairs has issued the "Standards for Children's Social Work Services" and the "Guidelines for the Work of Child Welfare Director," which provide specific guidelines for children's social work and set out, in detail, the duties, standards, and methods of the work of the child welfare director. The ministry has also carried out relevant training nationwide. However, this is a real challenge for the 620,000 child welfare directors and 48,000 child welfare supervisors throughout the country. The plight of children currently, compounded by the pandemic, economic downturn, and psychological anxiety, has posed even greater challenges for the children's social workers. For most of them, there is neither a professional foundation nor systematic training on how to conduct professional assessments and how to work with children, in terms of philosophy, knowledge, and skills, which need to be urgently supplemented and updated. Otherwise, there will be a bottleneck in carrying out children's work, and this will severely limit the further development of child protection. This work must be put on the agenda, with more research, materials, and curriculum design, and it shall catch up quickly. 
"Sometimes, I don't really know how to do it. There is training, but only two-day intensive training per year. It helps, but it really doesn't help much." (Child welfare director)

"I'm a children's social worker. But when I was at school, there was no specific course on children's social work. I just learned while doing it, and it was quite confusing at times." (Children's social worker)

“Our organization didn't do children's social work before. During the outbreak, the government bought our project. I don't have the knowledge and experience of working with children. I want to learn, but I can't find good learning materials and courses. For the whole of China, child protection has developed rapidly in recent years, but we are obviously not ready yet..." (Social worker of a Children in Difficulty Protection Project)

(iv) Research and exploration are needed to strengthen child protection in the postpandemic era.

In the face of such a major public health emergency, during the initial stage of the outbreak, both the government and social organizations failed in the relief and protection of children in difficulty to varying degrees. After this pandemic, there will be a need for special attention to how to learn lessons and bring the relief and protection of children in difficulty into the national public health system. After the initial outbreak, a social organization in Beijing called Collaborators conducted one-on-one online interviews with 46 families of migrant workers in distress. It was found that the support system for families in distress was very weak.

There was a lack of guidance on dealing with children's fear of the pandemic, and the children's perspective was missing in the community's epidemic prevention. With regard to teaching online, families in distress might not have smartphones, let alone access to videos. Therefore, children's perspectives should be taken into account in policymaking, the implementation of epidemic prevention measures, and community services to allow for making a rapid and effective assessment of children's needs. A government-social organization collaboration platform could be established, which could be activated quickly after a crisis, integrating all information and social resources to respond and form a unified system of action.

"Since the outbreak, more than 20 children suspected of suicide have been treated in our hospital, 12 of whom committed suicide with pills and 8 jumped from buildings. Compared with the same period of the previous year, the data is obviously high. I don't know what happened." (Medical social worker at a children's hospital)

"During the epidemic, we have encountered a lot of confusion or problems in the process of moving forward, and we hope that experts, including practitioners, will join us to crack and study them." (Children's work officer with the government)

"I hope that after the epidemic, or from the present moment, our policies will include the needs of every child and that our professional services will be delivered to those most marginalized... Next time, I hope that we don't start out as overwhelmed as we were this time." (Social worker of a Children in Difficulty Protection Project)

\section{Discussion}

The study showed that the COVID-19 pandemic had immediate positive effects on the development of China's child protection system for children in difficulty. Since the outbreak of COVID-19 in China, the central government has issued a series of targeted policies to incorporate the aid and protection of children in difficulty into the epidemic prevention system. Local governments quickly followed up and established a three-level prevention 
and protection system through the child director model, providing services for all children in difficulty. The local governments cooperated with social organizations by acquiring their professional services through project-based operations. This has contributed to the control of COVID-19 and the protection of children in difficulty. However, the pandemic also exposed some problems, and thereby, raised awareness of the need to develop the system after the pandemic.

At the heart of the results is the obvious lesson that there are problems and needs to be faced after the pandemic. A key point is that in the post-pandemic era, measures will need to be taken to solve these problems, such as the legalization and institutionalization of child protection, the training of professional talent for children's work, and the introduction of children's perspectives in major public health events. It remains to be seen what the longer term effects of the pandemic will be on the development of the child protection system and the situation of children in difficulty. In any case, the exceptional circumstances caused by the COVID-19 pandemic raised awareness of the need for special protection for vulnerable children and the importance of a functioning child protection system for social sustainability.

To the extent that child protection is seen as part of ensuring socially sustainable development, the fragmentation of the child protection system must be regarded as a detrimental factor. China's measures to protect children in difficulty in the event of an emergency caused by the COVID-19 pandemic demonstrate an effort to develop a comprehensive child protection system. There is ample evidence in the literature that the pandemic has highlighted a similar need in other countries, but as there has been no systematic analysis of this, it is difficult to form an overall picture. In any case, the pandemic has not only meant working under exceptional circumstances in the field of child protection, but has also emphasized the importance of the sector for social sustainability.

As COVID-19 is a major public health emergency, the protection of children during such a large-scale pandemic is a complex and systematic task. During the early outbreak, China lacked an effective emergency management mechanism for the protection of children in difficulty. However, as problems emerged, the central and local governments took immediate action and issued several policies related to children in difficulty in succession, and on the basis of policy formulation, implemented the policies through cooperation between government and social organizations. On the whole, China has made great achievements in responding to COVID-19 and in rescuing and protecting children in difficulty. However, there are some problems that need further exploration.

The overview of how the Chinese child protection system functioned in the exceptional circumstances caused by the pandemic, in particular to protect children in difficulty, confirmed that the appropriate governmental policies and smooth cooperation between the governmental administration and organizations responsible for implementation is a prerequisite for success. Accordingly, the study highlighted development needs in the field of child welfare. Three particular areas in need of development in child protection are legislation, the institutional system, and professionalism. These three areas are not separate but intertwined and must, therefore, be considered as a whole and in relation to each other.

As "crises can reveal disturbing sites of fragility and hidden reservoirs of strength" [37] (p. 33), the study showed that the COVID-19 pandemic has helped to identify the strengths and development needs of China's child protection policy and system. The analysis of the sustainability and effectiveness of child welfare in China in protecting children in difficult circumstances and their families from the negative social impact of the pandemic highlighted the need for comprehensive legislation, institutional system, and professional staff. The study provided indications that the lack of a special child protection law and the consequent fragmentation of the system, as well as the ambiguity of the responsibilities of authorities, hamper the proper coordination and systematic development of activities.

The COVID-19 pandemic has revealed similar needs for the development of a child protection system in other countries. In Italy, for example, attention has been drawn to the need to organize and coordinate services, especially for children and families with children 
in need of special assistance and support, and to support the work of child protection staff in changed circumstances [4]. The example of Italy shows not only that exceptional circumstances highlight similar development needs as those in China but also that actors in different countries can benefit from each other's experience and practical innovation. This also justifies the international relevance and necessity of country-by-country analyses.

In relation to the international literature, the Chinese experience reinforces the view that professionals working in child protection need special support to be able to respond to the unique needs of children living in vulnerable conditions under the exceptional circumstances caused by the pandemic [7]. The study also highlighted the importance of overall community sustainability in supporting children and families regarding comprehensive strengthening of the community service system to ensure proper care for children, which has also been highlighted in the international literature [5]. As the pandemic has raised new ethical issues concerning children and their rights in different countries, such as the issue of equality in education and the right to education [37], it also emphasizes the protection of those living in difficult circumstances as an ethical issue concerning society's obligations regarding children's rights, and particularly the rights of children in difficulty.

In addition to providing an overview of how the Chinese child protection system has worked to protect children in difficulty under the circumstances caused by the COVID19 pandemic, the study revealed specific development needs for the child protection system, particularly with regard to legislation, the organization of activities, and the capacity and role of professional staff. As the crisis has highlighted different development needs that reflect the characteristics of each society, an international comparison shows that the challenges of the exceptional circumstances caused by the COVID-19 pandemic for the resilience and development of China's child protection system have many of the same characteristics as in other societies.

Despite significant differences between countries in social and economic conditions and welfare systems, the examination of China's experience in light of the international literature shows that we can learn from each other. Research on the social impacts of COVID-19 on vulnerable children and the ability of national systems to play a child protection role under such exceptional circumstances provides not only information on country-specific characteristics but also universally valid aspects that can be widely applied in different societies.

As the sustainability of the system of implementation is a key factor in helping children at risk during the pandemic, appropriate policy and legislation are needed. Successful implementation requires appropriate legislation and a sufficient number of skilled professionals. The appropriateness of legislation depends on having a clear definition of the tasks and responsibilities of different actors including the regulation of the principles of cooperation. As China has ratified the International Convention for the Rights of the Child, this document is likely to be a key starting point for appropriate legislation that will form the basis of a sustainable system of implementation. Similarly, it also provides a point of reference for the professional development of the child welfare sector and the tasks of staff.

Methodologically, the study succeeded in creating a broader picture of child protection in China in the exceptional circumstances caused by the COVID-19 pandemic. The interviews and documents complemented each other, and the news material complemented the review of official documents perfectly. Case-specific analyses diversified and enriched the overall picture.

In the existing literature, only few Chinese researchers have addressed the protection of children in difficulty in major public health emergencies, such as the COVID-19 pandemic. It is necessary to further study and discuss topics such as the status quo of the protection of children in difficulty, the roles of the government and social organizations in the protection of children in difficulty, and issues requiring improvements, given the combined impact of infection and secondary disasters.

In addition, after such a public health emergency, we also need to learn from the lessons, study and reflect on the impact of COVID-19 on children's physiology and psy- 
chology, and find relevant influencing factors in order to have a better response next time. In particular, how should online services be developed when offline services are temporarily unavailable owing to the sudden outbreak of an epidemic or pandemic? The establishment and maintenance of offline communities differs substantially from the provision of face-to-face services. How can we integrate children's participation into services and develop children-oriented services? What changes will children in difficulty face as uncertainty rises and people lose control of their lives due to the epidemic/pandemic and economic downturn, and how can we prepare for them in advance? These problems must be studied, better regulated, and predicted on the basis of in-depth description and explanation.

The study was intended to explain the situation of child protection during the COVID19 pandemic in China. The interviews and case studies, however, were limited to the Shanghai area, and the cases from other areas referred to in the article are mostly case examples from evaluation reports, seminar summaries, and public news reports. The authenticity of the documents has been verified, but their limitations mean that the results remain limited in terms of geography and professional status. Further research should, therefore, diversify the interview material by interviewing more regional managers and practitioners and study more cases from other regions.

The main purpose this paper was to illustrate how the policy is introduced and implemented, so the voice of the child subject is not actually been addressed. In the future, research should continue to explore the lasting impact of policy on children in difficulty in the exceptional circumstances caused by the pandemic. As research on children's experiences and special needs increases in different countries, it is possible to both make structured international comparisons and to take a closer look at the links between children's experiences and the child protection systems and practices.

\section{Conclusions}

The results of the study suggest that the pandemic provided the impetus to develop China's child protection system more consciously as a coherent whole by raising awareness of the need to develop child protection as an integrated system. By creating awareness that tackling the problem of fragmentation requires a closer integration of laws, policies, and the service system with the local operating culture, the pandemic brought immediate political action in this direction on the way to better meeting the special needs of children in difficulty.

This study supports the notion that there should be closer cooperation between governmental departments as well as between governmental and non-governmental organizations to establish functional mechanisms for child protection and break down key barriers to the development in the field in terms of sustainable practices. The international literature shows that the COVID-19 pandemic has raised awareness of the need for comprehensive development of child protection in other countries as well.

While child protection systems and services for children and families vary from country to country, country-by-country analyses obviously provide useful information on how systems should be developed to enable them to face problems such as a large epidemic or pandemic. Both national child protection policies and the international academic community of scholars benefit from country-by-country analyses and comparisons of country-by-country experiences. At the same time, this article is a contribution emerging from international literature on the topic.

Author Contributions: F.Z., N.Z., and J.H. were responsible for conceptualization, writing, and editing; F.Z. and N.Z. for the methodology, data acquisition, and data analysis; and F.Z., N.Z., and J.H. for the results, discussion, and conclusions. All authors have read and agreed on the published version of the manuscript.

Funding: This research received no external funding. 
Institutional Review Board Statement: The study was conducted according to the guidelines of the Declaration of Helsinki, and approved by the Ethics Committee of The School of Social Development and Public Policy of Fudan University. (Protocol code FDU-SSDPP-IRB-2020-2-007 and date of approval is 23 November 2020).

Conflicts of Interest: The authors declare no conflict of interest.

\section{References}

1. Dong, Y.; Mo, X.; Qi, X.; Jiang, F.; Jiang, Z.; Tong, S. Epidemiology of COVID-19 among Children in China. Pediatrics 2020, 145. [CrossRef]

2. Caron, F.; Plancq, M.-C.; Tourneux, P.; Gouron, R.; Klein, C. Was child abuse inderdetected during the COVID-19 lockdown? Arch Pédiatrie 2020, 27, 399-401. [CrossRef] [PubMed]

3. Usher, K.; Durkin, J. Family violence and COVID-19: Increased vulnerability and reduced options for support. Int. J. Ment. Health Nurs. 2020, 29. [CrossRef] [PubMed]

4. Fontanesi, L.; Marchetti, D.; Mazza, C.; Di Giandomenico, S.; Roma, P.; Verroccio, M.C. The Effect of the COVID-19 Lockdown on Parents: A Call to Adopt Urgent Measures. Psychol. Trauma Theory Res. Pr. Policy 2020, 12, S79-S81. [CrossRef] [PubMed]

5. Fay, J.; Levinson, M.; Stevens, A.; Brighouse, H.; Geron, T. Schools During the COVID.19 Pandemic: Sites and Sources of Community Resilience. COVID-19 Rapid Response Impact Initiative. In COVID-19 White Paper 20; Edmond, J., Ed.; Safra Center for Ethics; Harvard University: Cambridge, MA, USA, 11 June 2020.

6. Rundle, A.G.; Park, Y.; Herbstman, J.B.; Kinsey, E.W.; Wang, Y.C. COVID-19-Related School Closing and Risk of Weight Gain among Children. Obesity 2020, 28. [CrossRef] [PubMed]

7. Priolo Filho, S.R.; Goldfarb, D.; Zibetti, M.R.; Aznar-Blefari, C. Brazilian Child Protection Professionals' Resilient Behavior during the COVID-19 Pandemic. Child Abus. Negl. 2020. [CrossRef] [PubMed]

8. Ministry of Civil Affairs of the People's Republic of China. The Notice of Carrying Out the Pilot Work of Building a Moderately Inclusive Child Welfare System. Minhan No. 206. 2013. Available online: http://www.china.com.cn/guoging/zwxx/2013-07/03 / content_29309610.htm (accessed on 15 August 2020).

9. Ministry of Civil Affairs of the People's Republic of China. The Notice on Launching the Second Batch of National Pilot Work for Social Protection of Minors. Minhan No. 240. 2014. Available online: http://smzt.gd.gov.cn/attachements/2019/01/05/a0f1f862 13753c366acb7a387cfb2b5b.pdf (accessed on 15 August 2020).

10. The Central People's Government of the People's Republic of China. The Guideline for Reinforcing Support for Children in Need Issued by the State Council. Guofa No. 36. 2016. Available online: http://www.gov.cn/zhengce/content/2016-06/16/content_ 5082800.htm (accessed on 15 August 2020).

11. China Philanthropy Research Institute. A Ten-Year Review and Prospect of China's Child Welfare and Protection Policy. Available online: http:/ / www.bnu1.org/show_1916.html (accessed on 29 May 2020).

12. Kevat, A. Children may be less affected than adults by novel coronavirus (COVID-19). J. Paediatr. Child Health 2020, 56, 657. [CrossRef]

13. Hawk, B.N.; Mccall, R.B.; Groark, C.J.; Muhamedrahimov, R.J.; Palmov, O.I.; Nikiforova, N.V. Caregiver sensitivity and consistency and children's prior family experience as contexts for early development within institutions. Infant Ment. Health J. 2018, 39, 432-448. [CrossRef] [PubMed]

14. Butler, M.J.; Barrientos, R.M. The impact of nutrition on COVID-19sceptibility and long-term consequences. Brain Behav. Immun. 2020, 87, 53-54. [CrossRef] [PubMed]

15. Covid, T.C.; Stephanie, B.; Virginia, B.; Nancy, C.; Aaron, C.; Ryan, G.; Matthew, R. Geographic Differences in COVID-19 Cases, Deaths, and Incidence-United States, 12 February-7 April 2020. Mmwr. Morb. Mortal Wkly. Rep. 2020, 69, 465-471. [CrossRef]

16. Ingersoll-Dayton, B.; Punpuing, S.; Tangchonlatip, K.; Yakas, L. Pathways to grandparents' provision of care in skipped-generation households in Thailand. Ageing Soc. 2018, 38, 1429-1452. [CrossRef]

17. Cluver, L.; Lachman, J.M.; Sherr, L.; Wessels, I.; Krug, E.; Rakotomalala, S.; Butchart, A. Parenting in a time of COVID-19. Lancet 2020, 395, e64. [CrossRef]

18. Galea, S.; Merchant, R.M.; Lurie, N. The mental health consequences of COVID-19 and physical distancing: The need for prevention and early intervention. JAMA Intern. Med. 2020, 180, 817-818. [CrossRef] [PubMed]

19. Yao, J.L. Some Reflections and Suggestions on the Juveniles Influenced by COVID-19. Available online: https://kns.cnki.net/ kcms/detail/detail.aspx?FileName=FZWT202001001\&DbName=CJFQ2020 (accessed on 15 August 2020).

20. Schwartz, J.; Yen, M.Y. Toward a collaborative model of pandemic preparedness and response: Taiwan's changing approach to pandemics. J. Microbiol. Immunol. Infect. 2017, 50, 125-132. [CrossRef] [PubMed]

21. Wilke, N.G.; Howard, A.H.; Pop, D. Data-informed recommendations for services providers working with vulnerable children and families during the COVID-19 pandemic. Child Abus. Negl. 2020. [CrossRef] [PubMed]

22. Beijing Youth Daily-YNET. A Local Joint Investigation Team Was Established after the Death of a 17-Year-Old Cerebral Palsy Teenager Boy in Huangguang Who Died Six Days after His Father Was Quarantined. Available online: http:/ / news.ynet.com/20 20/01/30/2351377t70.html?from=groupmessage (accessed on 30 January 2020). 
23. The Elderly in Shiyan, Hubei Province Died at Home, Leaving behind the 6-Year-Old Grandson. The Story of Left-Behind Children during the Epidemic is Heartbreaking. Available online: https://www.sohu.com/a/376075361_120582926 (accessed on 26 February 2020).

24. Because of no Phone Available for Online Courses, a Girl Committed Suicide? Her father: The School Will Have an Exam on the Day of the Accident. Netease News. Available online: http://news.163.com/20/0302/00/F6M3V2AQ00019B3E.html (accessed on 2 March 2020).

25. Ministry of Civil Affairs of the People's Republic of China. The Notice on the Care and Protection for Children Left Unattended after the Virus Outbreak. Mindian No. 19. 2020. Available online: http://xxgk.mca.gov.cn:8011/gdnps/pc/content.jsp?id=1415 $0 \& m$ type $=($ accessed on 15 August 2020).

26. The Central People's Government of the People's Republic of China. A Circular of Proposing Measures to Care for, Protect and Aid Children Left Unattended after the Virus Outbreak Issued by the State Council's Joint Prevention and Control Mechanism for the Novel Coronavirus (COVID-19) Epidemic. Guofamingdian No. 11. 2020. Available online: http://www.gov.cn/zhengce/ content/2020-03/15/content_5491581.htm (accessed on 15 August 2020).

27. The Central People's Government of the People's Republic of China. The Circular of Urging Prevention and Control of the COVID-19 Outbreak in Civil Service Institutions Released by the State Council. Guofamingdian No. 6. 2020. Available online: http:/ / www.gov.cn/zhengce/content/2020-02/28/content_5484533.htm (accessed on 15 August 2020).

28. Ministry of Civil Affairs of the People's Republic of China. The Notice of the Ministry of Civil Affairs and the Poverty Relief Office of the State Council on the Action Plan of Social Assistance for the Needy. Minfa No. 18. 2020. Available online: http:/ / xxgk.mca.gov.cn:8011/gdnps/pc/ content.jsp?id=13759\&mtype= (accessed on 15 August 2020).

29. Ministry of Civil Affairs of the People's Republic of China. The notice of the Ministry of Civil Affairs on the Organization of "Policy Preaching into Villages (Communities)" Activity for left-behind Children and Children in Need in Rural Areas Nationwide. Minhan No. 55. 2020. Available online: http:/ /xxgk.mca.gov.cn:8011/gdnps/pc/content.jsp?id=14148\&mtype $=($ accessed on 15 August 2020).

30. Ministry of Civil Affairs of the People's Republic of China. The Notice of the Ministry of Civil Affairs and The Ministry of Finance on Further Improving the Work of Ensuring Basic Living Allowances for Poverty-Stricken People. Minfa No. 69. 2020. Available online: http:/ /xxgk.mca.gov.cn:8011/gdnps/pc/content.jsp?id=14545\&mtype= (accessed on 15 August 2020).

31. The Central People's Government of the People's Republic of China. The Directive on Reforming and Improving the Country's Social Assistance System Released by the General Offices of the Communist Party of China Central Committee and the State Council. 2020. Available online: http:/ /www.gov.cn/zhengce/2020-08/25/content_5537371.htm (accessed on 15 August 2020).

32. Ministry of Civil Affairs of the People's Republic of China. The Notice of the General Office of the Ministry of Civil Affairs and the General Office of the Ministry of Justice on Ensuring the Care and Protection of Minors in Detention and Compulsory Treatment of Drug Addicts' Families. Minbanfa No. 24. 2020. Available online: http:/ xxgk.mca.gov.cn:8011/gdnps/pc/content. jsp?id=14542\&mtype $=($ accessed on 15 August 2020).

33. Shanghai Civil Affairs Bureau. A Circular of Proposing "Love with Children"-Work Plan of Shanghai Assistance and Care Project for Children in Need. Huminerfufa No. 2. 2020. Available online: https://mzj.sh.gov.cn/MZ_zhuzhan278_0-2-8-15-55-2 30/20200519/MZ_zhuzhan278_48124.html (accessed on 15 August 2020).

34. "Zero infection" in the Welfare Institutions for Children and the Assistance and Protection Institutions for Minors. gov.cn. Xinhua News Agency. Available online: http:/ /www.gov.cn/xinwen/2020-04/24/content_5505900.htm (accessed on 24 April 2020).

35. Ministry of Civil Affairs of the People's Republic of China. The Notice of the Ministry of Civil Affairs on the Pilot Areas of the Unified National Child Assistance and Protection Hotline. Minhan No. 69. 2020. Available online: http:/ /xxgk.mca.gov.cn: 8011/gdnps / pc/content.jsp?id=14586\&mtype=1 (accessed on 15 August 2020).

36. Ministry of Civil Affairs of the People's Republic of China. 2019 Civil Affairs Development Statistical Bulletin. Available online: http:/ /images3.mca.gov.cn/www2017/file/202009/1599546296585.pdf (accessed on 15 August 2020).

37. Levinson, M. Educational Ethics during a Pandemic. COVID-19 Rapid Response Impact Initiative. In COVID-19 White Paper 17; Edmond J. Safra Center for Ethics; Harvard University: Cambridge, MA, USA, 16 May 2020. 